\title{
Akutansi Forensik Dalam Upaya Pemberantasan Tindak Pidana Korupsi
}

\author{
H. Hasriyanti \\ Fakultas Hukum, Universitas Muhammadiyah Sorong \\ Email : Harunhasriyanti@gmail.com
}

\begin{abstract}
Abstrak
Korupsi telah menjadi isu yang fenomenal dan selalu menarik untuk dibahas di Indonesia. Korupsi telah dianggap sebagai akar penyebab masalah nasional, seperti ekonomi biaya tinggi, pertumbuhan ekonomi, dan hambatan investasi, berfokus pada kesempatan menerapkan konsep akuntansi forensik dalam memberikan bukti untuk mendukung keputusan pengadilan. Penelitian ini bertujuan untuk mengkaji peran akuntansi forensik melalui pendekatan preventif, detektif, dan korektif untuk mencegah dan menangani korupsi di Indonesia. Model segitiga penipuan Cressey digunakan untuk memetakan peran akuntansi forensik dalam mencegah korupsi.
\end{abstract}

Kata Kunci : Tindak Pidana Korupsi, Akutansi Forensik, Pemberantasan

\section{PENDAHULUAN}

Menjamurnya praktik-praktik korupsi hampir di setiap lini kehidupan di Indonesia sangat ironis dengan banyaknya strategi yang telah dirumuskan oleh berbagai lembaga pemerintahan seperti BPK, BPKP, Inspektorat,KPK maupun oleh kalangan LSM seperti MTI dan ICW. Seluruh strategi yang merupakan jurus-jurus ampuh dalam pemberantasan korupsi yang sudah menggejala.

Sulitnya memberantas korupsi di Indonesia mengingatkan pada suatu konsep yang disebut capture theory dari Amle $\mathrm{O}$ Krueger. capture theory menyatakan bahwa segala sesuatunya di atas kertas secara yuridis formal adalah sah dan legal. Sayangnya pada tataran realitasnya teori ini banyak disalahgunakan untuk memuluskan kepentingan beberapa pihak. Pendekatan akutansi forensik akan sangat membantu dalam menganalisis berbagai kasus korupsi di Indonesia khususnya yang berkaitan dengan korupsi sistemis yang dilakukan melalui konspirasi yang telah dipersiapkan dengan dukungan dokumen legal oleh para pelakunya.

Berbagai kasus memperlihatkan bahwa yang diutamakan dalam mempertanggungjawabkan suatu pekerjaan adalah dalam rangka memenuhi persyaratanpersyaratan formal yang akan diminta oleh pemeriksa. Misalnya keharusan adanya kuitansi pengeluaran, daftar hadir rapat untuk pembayaran honor atau tiket pesawat terbang san bording pass dalam kasus-kasus pertanggungjawaban belanja. Dokumen-dokumen formal yang disiapkan 
atau khusus disiapkan untuk mengesankan bahwa secara yuridis formal sebuah belanja adalah legal padahal di dalamnya ada upaya rekayasa dengan dokumen fiktif, konsipirasi pelaksanaan tender atau mark up.

Dihadapkan pada korupsi yang melibatkan prakti-praktik sistemis dan melembaga seperti yang dijelaskan oleh capture theory membuat upaya dan strategi pemberantasan korupsi menjadi semakin rumit. Strategi dalam pemberantasan korupsi setidaknya harus memuat dua persyaratan yaitu adanya komitmen politik nasional untuk memberanitas korupsi dan adanya sejumlah aktivitas yang dapat dilihat oleh masyarakat luas sebagai entry-point atau pintu masuk pemberantasan korupsi.

Berbagai aturan perundang-undangan sesungguhnya telah memuat komitmen poliik secara resmi. Demikian pula komitmen politik rakyat secara konkret telah dibuktikan dalam banyak kegiatan unjuk rasa, demonstrasi, diskusi, pernyataan pendapat, analisis dan saran-saran yang dilakukan oleh berbagai unsur masyarakat yang menyatakan agar segera dihapuskannya praktik-praktik KKN (korupsi, kolusi, dan nepotisme).

Berkaitan dengan entry-point diperlukan adanya srategi pemberantasan korupsi nasional yang disosilisasikan kepada masyarakat luas serta adanya upaya nyata untuk memperkuat lembaga-lembaga yang berwenangan untuk pemberantasan korupsi. Berikutnya adalah tersedianya profesional dengan kompetensi memadai untuk melacak dan membuktikan suatu kejadian korupsi. Kompetensi profesional yang dilindungi oleh lembaga profesi khususnya profesi akuntan forensik belum ada dan belum digunakan dalam pengungkapan dan pemberantasan kasus korupsi di indonesia. Artikel ini mengkaji strategi pemberantasan korupsi serta potensi dari akuntansi forensik sebagai ilmu dan akuntan forensik sebagai profesi dalam pemberantasan korupsi di indonesia. Artikel ini memfokuskan pembahasan pada peran akutansi forensik dalam upaya pengungkapan dan penyelesaian kasus korupsi melalui pemutusan mata rantai model segi tiga kecurangan fraund trianglei dari Donald R. Cressy.

Konsep akutansi forensik, korupsi, strategi pemberantasan korupsi fraud triangle serta penelitian empiris tentang korupsi dibahas untuk mengkonstruksi pembahasan peran akutansi forensik dalam pemberantasan korupsi. Akutansi forensik sebagai aplikasi ilmu akutansi diarahkan untuk mampu menyediakan informasi, bukti dan pembuktian yang memadai untuk debat pada persidangan di pengadilan. 
Akuntansi Forensik : Terminologi akuntansi forensik dibahas untuk referensi dalam formulasi strategi pemberantasan korupsi. Forensik accounting, forensik investigation, forensik audit, dan litigation support adalah beberapa terminologi penting dalam memahami akutansi forensik sebagai bagian dari ilmu akutansi yang bermanfaat dalam penyelesaian dan pencegahan tindak pidana korupsi. Beberapa terminologi ini dibahas sebagai berikut:

Forensik accounting : Forensik accounting, provides an accounting analysis that is suitable to the caure which will form the basis for discussion, debate and ultimately dispute resolution. akutansi forensik, menyediakan suatu analisis akutansi yang dapat digunakan dalam perdebatan di pengadilan yang merupakan basis untuk diskusi serta resolusi di pengadilan. Penerapan pendekatan-pendekatan dan analisis-analisis akutansi dalam akutansi forensik dirancang untuk menyediakan analisis dan bukti memadai atas suatu asersi yang nantinya dapat dijadikan bahan untuk pengambilan berbagai keputusan di pengadilan.

Forensik Investigation : The utilization of specialized investigative skills in carrying out an inquiry conducted in such a manner that the outcome will have application to a court of law. A Forensik investigation may be grounded in accounting, medicine,engineering or some other discipline.

Investigasi forensik pemanfaatan keterampilan khusus dalam penyelidikan untuk menyelesaikan suatu permintaan pemeriksaan yang hasilnya akan mempunyai aplikasi atau digunakan untuk kepentingan di pengadilan. Suatu penyelidikan forensik mungkin didasarkan pada akuntansi, obat kedokteran, rancang-bangun atau beberapa disiplin lain. Prinsipnya forensik investigasi merupakan penerapan teknik-teknik auditing yang ditujukan dan dirancang khusus untuk mencari atau menemukan bukti dan pembuktian atas suatu pengungkapkan keuangan yang nantinya dapat digunakan dalam proses persidangan di pengadilan.

Forensik audit : An examination of evidence regarding an assertion to determine its correspondance to established criteria carried out in a manner suitable to the court.

Suatu pengujian mengenai bukti atas suatu pernyataan atau pengungkapan informasi keuangan untuk menentukan keterkaitannya dengan ukuran-ukuran standar yang memadai untuk kebutuhan pembuktian di pengadilan. Audit forensik lebih menekankan proses pencarian bukti serta penilaian kesesuaian bukti atau temuan audit tersebut dengan ukuran pembuktian yang dibutuhkan untuk proses persidangan. Audit forensik merupakan perluasan dari penerapan prosedur audit standar ke arah pengumpulan bukti untuk kebutuhan persidangan di pengadilan. 
Litigation support : "litigation support", provides assistance of an accounting nature in a matter involving existing or pending ligiation. It deals primarily with issues related to the quantification of economic damages. A typical litigation support assignment would be calculating the economic loss resulting from a breach of contract.

Litigation support menyediakan bantuan dari pengetahuan akutansi dalam hal menyatakan ada atau menunda proses pengadilan terutama mengenai isu yang berhubungan dengan kuantifikasi dari kerusakan ekonomi. Jadi dukungan pengadilan menyediakan dukungan mengenal perhitungan kerugian ekonomi dari dilanggarnya suatu kontrak atau tugas publik yang dibebankan kepada seseorang karena jabatannya.

\section{PEMBAHASAN}

\section{Pendekatan perumusan strategi dalam upaya pemberantasan korupsi}

Analisis atau perbuatan-perbuatan korupsi dapat didasarkan pada berbagai pilihan pendekatan. Berdasarkan pendekatan yang di pilih, selanjutnya dapat dirumuskan strategi untuk pencegahan dan pemberantasan korupsi yang tepat. Praktik korupsi dapat dilihat berdasarkan aliran prosesnya, yaitu dengan melihatnya pada posisi sebelum perbuatan korupsi terjadi, padaposisi perbuatan korupsi terjadi dan pada posisi setelah perbuatan korupsi terjadi.

Pada posisi sebelum perbuatan korupsi terjadi upaya pencegahannya bersifat preventif. Pada posisi perbuatan korupsi terjadi upaya mengidentifikasi atau mendeteksi terjadinya korupsi bersifat detektif. sedangkan pada posisi setelah perbuatan korupsi terjadi upaya untuk menyelesaikan secara hukum dengan sebaik-baiknya bersifat represif.

Strategi preventif harus dibuat dan dilaksanakan dengan diarahkan pada hal-hal yang menjadi penyebab timbulnya praktik korupsi. Setiap peyebab korupsi yang teridentifikasi harus dibuat upaya preventifnya, sehingga dapat meminimalkan penyebab korupsi. Disamping itu, perlu dibuat upaya yang dapat meminimalkan peluang untuk melakukan korupsi.

Strategi detektif harus dibuat dan dilaksanakan terutama dengan diarahkan agar apabila suatu perbuatan korupsi terlanjur terjadi maka perbuatan korupsi terlanjur terjadi maka perbuatan tersebut akan dapat diketahui dalam waktu yang singkat dan akurat. Deteksi dini mengenai suatu tindakan korupsi dapat mempercepat pengambilan tindak lanjut dengan tepat sehingga akan menghindarkan kerugian lebih besar yang mungkin timbul. 
Strategi represif harus dibuat dan dilaksanakan terutama dengan diarahkan untuk memberikan sanksi hukum yang setimpal secara cepat dan tepat kepada pihak-pihak yang terlihat dalam praktik korupsi. Dengan demikian, proses penanganan korupsi sejak dari tahap penyelidikan, penyidikan dan penuntutan sampai dengan peradilan perlu dikaji untuk dapat disempurnakan di segala aspeknya sehingga proses penanganan tersebut akan dapat dilakukan secara cepat dan tepat.

Akuntansi forensik dalam konteks preventif, detektik, dan represif secara aksiomatis dapat mengambil peranannya dengan menyediakan pendekatan-pendekatan yang efektif dalam mencegah, mengetahui atau mengungkapkan dan menyelesaikan kasus korupsi. Untuk kepentingan ini akutansi forensik di indonesia belum banyak digunakan karena profesi akutansi belum mentapkan standar dari penerapan akutansi forensik sebagai salah satu profesi akuntan.

Akuntansi forensik dan profesi akuntan forensik yang di negara-negara maju mengambil peran strategis dalam pengungkapan kecurangan termasuk korupsi di indonesia belum begitu umum peranannya. Kondisi ini tidak terlepas dari belum ditetapkannya standar untuk profesi ini dan belum dimasukkannya akuntansi forensik dalam kurikulum perguruan tinggi yang menghasilkan tenaga akuntan. Pendidikan akuntan forensik merupakan sinergi dari pendidikan tinggi dan profesi akuntansi yang secara khusus dalam kurikulumnya memberikan dasar-dasar ilmu hukum khusus yang berhubungan dengan pembuktian dan alat bukti perkara.

Akuntansi forensik dengan pendekatannya yang efektif dalam mengungkap dan menyediakan alat bukti tindak kejahatan korupsi di pengadilan dalam perspektif fraud triangle tentu memiliki aplikasi yang luas. Akuntansi forensik dengan profesi akuntan forensiknya dapat menghambat keyakinan dari pelaku atau calon pelaku korupsi bahwa ada peluang untuk melakukan korupsi dan tidak ada profesi atau lembaga yang akan mampu mengungkapkannya.

Keyakinan bahwa tindakan-tindakan korupsi tidak akan diketahui baik dalam bentuk transactive corruption, autogenic corruption, nepotistic corruption investive corrution, exartive corruption maupun defensive corruption menjadi terbatasi karena ada profesi kompeten yang akan menginvestigasi. Dalam konteks ini akuntansi forensik berperan sebagai strategi preventif untuk mencegah tindak pidana korupsi karena ada kekhawatiran dari pelaku bahwa korupsi yang dilakukan dengan mudah akan terungkap oleh para akuntan forensik.

Akuntansi forensik juga dapat mengambil peranan dalam upaya pengungkapan tindak pidana korupsi atau strategi detektif. secara sistemis prosedur-prosedur investigasi dalam audit 
forensik memang berbeda dari auditing pada umumnya. Audit forensik yang sejak awal memang dirancang guna mengumpulkan dan menyediakan bukti untuk kepentingan persidangan di pengadilan akan menghasilkan temuan audit yang lebih bermanfaat dibandingkan dengan audit umum yang disediakan oleh jasa profesi akuntan. Dalam konteks strategi detektif audit forensik menerapkan prosedur-prosedur investigasi unik yang memadukan kemampuan investigasi bukti keuangan dengan muatan transaksinya dengan investigasi tindakan pidana dengan muatan untuk mengobvervasi niat atau modus operandi dari pelakunya

Peran akuntansi dan kuntan forensik di negara maju dalam pengungkapan dan penyelesaian kasus fraud termasuk korupsi sangatlah besar. Sayangnya indonesia belum memiliki lembaga legal untuk profesi dan juga institusi pendidikan formal untuk menghasilkan akuntan forensik yang kompeten. Kondisi ini tentu membutuhkan perhatian dari profesi akuntan di indonesia khususnya dari kompartemen akuntan pendidik maupun kompartemen lainnya. Perhatian tersebut dapat berupa sumbangan kajian empiris atau konseptual mengenai bagaimana kelembagaan ideal dari profesi akuntan forensik di indonesia dan bagaimana sistem pendidikan dan kurikulum ideal untuk menghasilkan tenaga akuntan forensik yang kompeten. Penelitian empiris juga penting dilakukan untuk menguji tipologi korupsi dan relevansi model fraud triangle yang mendorong orang melakukan tindakan korupsi di indonesia

\section{SIMPULAN}

Akuntansi forensik merupakan formulasi yang dapat dikembangkan sebagai strategi preventif, detektif, dan persuasif melalui penerapan prosedur audit forensik dan audit investigatif yang bersifat litigation support untuk menghasilkan temuan dan bukti yang dapat digunakan dalam proses pengambilan putusan di pengadilan.

Belum tersedianya institusi yang menghasilkan tenaga akuntansi forensik dan audit forensik memerlukan upaya dari institusi penyelenggaraan pendidikan dalam menyediakan kurikulum yang membekali lulusan dengan kompetensi akuntansi forensik.

Belum tersedianya lembaga dan standar profesi auditor dan akuntan forensik merupakan tantangan bagi profesi akuntansi di indonesia untuk mengoptimalkan peran profesi dalam penanganan kasus korupsi.

\section{DAFTAR PUSTAKA}


Achawan, Rochman. 2000. "Good Governance: Manifesto politik abad ke 21". Kompas, 28 juni 2000.

Ackerman, susan rese, 1999. "Ekonomi politik korupsi" dalam Elliott, kimberly Ann, Ed. (19:x9) Korupsi dan Ekonomi Dunia. Jakarta: Yayasan Obor Indonesia.

Adji, Indriyanto seno. 1999. "Menuju UU Tindak Pidana Korupsi yang Efektif". Kompas Online, http www kompas com/9709/25/Opini menu html

Alatas, Syed Hussain, 1987. Korupsi sifat, sebab dan fungsi. Jakarta: LP3ES. Lubis, Mochtar dan Jarnes C. Scott Ed. 1988. "Bunga Rampai Korupsi”. Jakarta: LP3ES.

Mauro, paolo. 1995. "Corruption and Growth”. Quarterly Journal of Economics. August, pp. 681-712

Media Indonesia Online. 1997. "korupsi Membuat Investor Meyingkir, pertemuan Bank DuniaIMF Ditutup", http//www.rad.net.id/online/mediaind/publik/9709/26/MIOI-04.26.html1

Mugirahardjo. 1997. "korupsi dalam Menyonsong Era Liberalisasi”. Suara Pembaruan Online, http:www.suarapembaruan.com/News/1997/02/250297/OpEd/opdO1/opdO1.html1

Saefuddin Ahmad Muflih. 1997' “Korupsi Struktural”. Gatra lnfo Service. http://www gatra.com/111/28/kol6-28.html

Wibisono, Christianto.1999. "Defisit Transaksi, kolusi, dan korupsi", Suara pembaruan Online, http://www.suarapembaruan.com/News/1996/12/021296/Headline/hl14/hl14.html

Yakup, Bahrul Iimi. 1996."kualitas pengadilan Indonesia Terburuk di Asean”. Republika Online, http://www.republika.co.id./last/ 